\title{
Critical Factors that Determine Credit Approval to Micro, Small, and Medium Enterprises
}

\author{
Halim Putera Siswanto', Agus Zainul Arifin², Cavin ${ }^{3}$
}

\begin{abstract}
Many business owners attempt to apply for bank credit, but not all of them are approved. This study aims to reveal the factors determining credit approval to Micro, Small, and Medium Enterprises (MSME). The variables used in this study are the owner's capital, company establishment, collateral value, credit amount, owner's age, and good relationship with the bank. In this study, the logit model used as a technique of analysis, in which there is only one dependent variable in the form of dummy along with the other six independent variables. The statistical test reveals that simultaneously all independent variables have significant effects on credit approval. Partially, only the owner's capital and good relationships with the bank do affect the approval. Therefore, business owners should pay more attention to their amount of capital and interrelation with the bank when applying for bank credit.
\end{abstract}

Keywords: credit approval, logistic regression, micro, small, and medium enterprises (MSME)

JEL Classification: C30, G21

\begin{abstract}
Abstrak. Banyak pemilik usaha berupaya untuk mengajukan kredit kepada bank, namun tidak semua pengajuan tersebut disetujui. Penelitian ini berusaha untuk mengungkapkan faktor-faktor yang menentukan persetujuan pembeian kredit kepada Usaha Mikro, Kecil, dan Menengah (UMKM). Variabel-variabel yang digunakan adalah modal pemilik, lama berdirinya usaha, nilai jaminan, jumlah kredit, usia pemilik, dan hubungan baik dengan pihak bank. Di dalam penelitian ini, digunakan model logit yang mana hanya terdapat satu variabel dependen dalam bentuk dummy bersama dengan enam variabel independen lainnya. Hasil pengujian statistik mengungkapkan bahwa secara simultan seluruh variabel independen memiliki pengaruh yang signifikan terhadap persetujuan pemberian kredit. Secara parsial hanyalah modal pemilik dan hubungan baik dengan pihak bank yang menentukan persetujuan pemberian kredit tersebut. Oleh karena itu, para pemilik usaha perlu memberikan perhatian lebih kepada besarnya modal yang dimiliki dan hubungan baik yang terjalin dengan pihak bank ketika mengajukan kredit kepada bank.
\end{abstract}

Kata Kunci: persetujuan kredit, regresi logistik, usaha mikro, kecil, dan menengah (UMKM)

\section{How to Cite:}

Siswanto, H. P., Arifin, A. Z., \& Cavin. (2019). Critical Factors that Determine Credit Approval to Micro, Small, and Medium Enterprises. Etikonomi: Jurnal Ekonomi. Vol. 18 (1): 93 - 104. doi: http//dx.doi.org/10.15408/etk.v18i1.6722. 


\section{Introduction}

In Indonesia, many kinds of micro, small, and medium-scale business can drive the national economy. The fundamental problem for these businesses is related to access to a financing source, market and marketing, good governance, and information. The difficulty for these businesses to access the source of financing occurs due to the lack of information and the capability to reach those sources. Micro, Small, and Medium Enterprises (MSME's) commonly do not have a good quality of financial statements making the banks think doubtfully about the relevancy and the reliability of those financial reports (Rudiantoro \& Siregar, 2012). However, the bank is still the most significant source of financing that can be utilized by the owners of MSME. In order to build a good partnership with the bank, those owners are obliged to provide feasible business proposals. Besides, financial institutions (mainly banks) require such kinds of business to be bankable, which means that they have to fulfill all the terms and conditions determined by their banks.

Banking institutions have important roles for every business unit to support the daily business activities. Bank can help to assist business owners in preparing good business records so that the use of funds can control which finally can bring positive impacts for business operations. By training and assisting the MSME, the owners can have good administration system, and the result can be used to convince the banks in order to approve their future credit applications.

One obstacle in developing MSME is the lack of fund that can utilize as capital in order to support the increasing amount of production. This phenomenon happens because most business owners have not met the $5 \mathrm{C}$ requirement determined by the banks. Thus, the MSME's access to financial institutions is still relatively limited. The capital required to develop MSMEs and cooperatives still relies more from personal equity and the reuse of acquired/retained earning. As long as the business owners want to develop their MSME's, the need for external financing will continuously exist. The MSME's access to the bank as their source of financing still needs to be enhanced by integrating the involvements of government, business associations, social communities, as well as higher educational institutions (Susilo, 2010; De La Torre et al., 2010).

The Small Business is an economically productive business, which is independent, managed by individuals or institutions. Degreyse et al., (2018) find that the SMEs have stronger financial conditions faced greater credit availability. The elements contained in credit approval are trust, agreement, time-period, risk, and compensation (Kasmir, 2004). Jumhur (2009) concludes that asset size and interest-rate in other financial institution have a positive relationship on the probability of small business to apply for working capital credit.

Messah \& Wangai (2011) find that there is a significant effect on the decision to apply for credit. Meanwhile, numbers of burden and business attributes do not affect the dependent variable significantly. Moreover, the variables of age, gender, income, location, business sector, and numbers of manpower have a positive relationship with the decision to apply for bank credit. Meanwhile, numbers of burden, company establishment, and interestrate have a negative relationship with the dependent variable. 
Ajagbe (2012) find that there is a positive relationship between gender, familysize, asset values, education, period to acquire credit, and contribution from the credit market with informal credit source. On the other hand, the variables of age, membership composition, period to acquire credit, and business condition have a negative relationship with the dependent variable. For formal credit source, the variables of family-size, asset value, education, and business condition, have a positive relationship with the dependent variable. Instead, the variables of gender, age, membership composition, period to acquire credit, and contribution from the credit market, have a negative relationship. Finally, only age, membership composition, asset values, and education have a significant effect on credit source preferences, either formally or informally. Pato (2013) revealed that financial ratio analysis and collateral value becomes the most critical part of the process of credit approval by the bank.

Geographically, this study focusses on Bekasi City, because this city considered as the satellite area of Jakarta, which is the capital city of Indonesia. Furthermore, not many researchers in the past have conducted studies on the determination of credit approval for MSME in this city. By revealing the critical factors that determine credit approval for MSME, the necessary procedures can be prepared by MSME management so that the credit application can be readily granted or approved by the banks in the future.

This study aims to examine the critical factors that determine credit approval in micro, small, and medium enterprises. This study using a logistic regression analysis to examine, which factors that, determines the probability of credit approval to MSME. This study will give a significant contribution to give the critical factors that determine credit approval to MSME.

\section{Methods}

This study conducted in the area of Bekasi City. MSME that became the samples of this study did not have any records about their business conducts. Therefore for this study, using collected data: first, interview with Account Officer of a Bank located in Bekasi City; Second, questionnaires to acquire information from MSME executives; Third, observation on documents possessed by a private bank in Bekasi about the data on MSME owners.

The population of this study is all MSMEs in Bekasi City, which are as many as 10,834 units. The samples in this study are bank deposits in the category of MSME owners who applied the credit to a branch of a private bank located in Bekasi City by using simple random sampling. In order to determine the amount of minimum sample, Slovin formula applies. The sample size in this study is 100 samples.

In this study, the logit model used in which there is only one dependent variable in the form of dummy (the result of credit analysis; approved $=1$ and not approved $=0$ ) along with the other six independent variables. The logistic regression model used to test the entire hypothesis is as follow: 
$\begin{aligned} \operatorname{Ln} \frac{P}{1-P} & =\alpha+(\beta 1 . \text { Owner's Capital })+(\beta 2 . \text { Company Establishment })+(\beta 3 \text {. Collateral Value }) \\ & +(\beta 4 . \text { Credit Amount })+(\beta 5 . \text { Owner's Age })+(\beta 6 . \text { Good Relationship with the Bank })\end{aligned}$

Several stages in data analysis that have to complete are Multicollinearity Test, Hosmer and Lemeshow's Goodness-of-Fit Test, Model-Fit Test, Model Summary, Classification Table, Omnibus Test of Model Coefficient, and Partial Test (t-test).

\section{Result and Discussion}

Table 1 shows that the correlation coefficients among independent variables are less than 0.900 , which means that there are no strong correlations among those variables. Thus this model does not contain multicollinearity effect.

Table 1. Correlation Matrix

\begin{tabular}{lccccccc}
\hline & Constant & OC & CE & CV & CA & OA & GR \\
\hline Step Constant & 1.000 & .306 & -.129 & -.090 & -.211 & .768 & -.292 \\
Owner's Capital (OC) & .306 & 1.000 & .081 & -.343 & -.684 & -.222 & .112 \\
Company Establishment (CE) & -.129 & .081 & 1.000 & -.021 & -.131 & -.201 & -.103 \\
Collateral Value (CV) & -.090 & -.343 & -.021 & 1.000 & -.292 & -.129 & .084 \\
Credit Amount (CA) & -.211 & -.684 & -.131 & -.292 & 1.000 & .204 & -.194 \\
Owner's Age (OA) & -.768 & -.222 & -.201 & -.129 & .204 & 1.000 & -.109 \\
Good Relationship (GR) & -.292 & .112 & -.103 & .084 & -.194 & -.109 & 1.000 \\
\hline
\end{tabular}

The feasibility of the regression model assesses by using Hosmer and Lemeshow's Goodness-of-Fit Test. Significance value greater than 0.05 means that H0 cannot reject, thus this model can be accepted due to its conformity to the observation data. Table 2 shows that Chi-square value is 25.816 with a significance value of 0.211 (greater than $\alpha$ ) and Degree of Freedom (df) of 8. This result means that there is no difference between predicted and observed classification. Therefore, the logistic regression model used in this study has met the data fit.

Table 2. Hosmer and Lemeshow's Goodness-of-Fit Test

\begin{tabular}{cccc}
\hline Step & Chi-Square & df & Sig. \\
\hline 1 & 25.816 & 8 & .211 \\
\hline
\end{tabular}

This test did by comparing the values between -2 log likelihood (-2LL) in the beginning (Block Number $=0)$ and that in the end (Block Number $=1$ ). The reduction of value, in the end, shows that the hypothesized model has fit the data. The Log Likelihood in the logistic regression model is similar to the Sum of Square Error in linear regression. Thus, the lower 
the value of log likelihood, the better this model will be. The result of Model-Fit Test can show in Table 3 and Table 4.

Table 3. Model-Fit Test 1: Iteration History

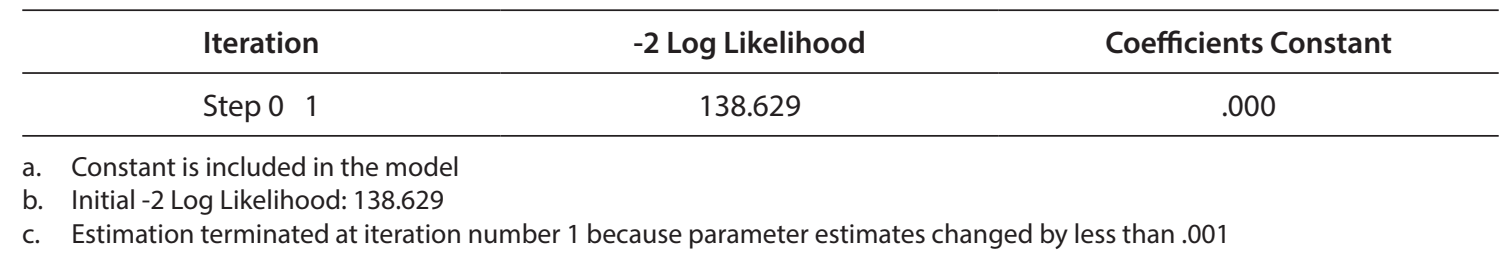

Table 3 and Table 4 show the comparison between the value of -2LL in the first block and that in the second block. The value of $-2 \mathrm{LL}$ in the first block (Block Number $=0$ ) is 138.629 and the end-value of -2LL in the second block (Block Number $=1$ ) is 78.475 . From this result, it can conclude that the second regression model is better because the value declines in the second block.

In logistic regression, the model summary is similar to the R2 test in a linear regression model. The objective in model summary is to find out how well the variation in independent variables (Owner's Capital, Company Establishment, Collateral Value, Credit Amount, Owner's Age, and Good Relationship with the Bank) can explain the variation in the dependent variable, which is the probability of credit approval. The result of the model summary can show in Table 5.

Table 4. Model-Fit Test 2: Iteration History

\begin{tabular}{ccccccccc}
\hline $\begin{array}{c}\text { Iteration } \\
\text { Step 1 }\end{array}$ & $\begin{array}{c}-2 \text { Log } \\
\text { Likelihood }\end{array}$ & Constant & OC & CE & CV & CA & OA & GR \\
\hline 1 & 87.206 & -2.017 & -.351 & .028 & .317 & .117 & .002 & 2.130 \\
2 & 80.868 & -2.837 & -.642 & .028 & .524 & .439 & .004 & 2.575 \\
3 & 78.815 & -3.206 & -.964 & .018 & .689 & .897 & .007 & 2.635 \\
4 & 78.485 & -3.381 & -1.148 & .016 & .765 & 1.190 & .008 & 2.631 \\
5 & 78.475 & -3.420 & -1.186 & .016 & .778 & 1.251 & .009 & 2.631 \\
6 & 78.475 & -3.422 & -1.187 & .016 & .779 & 1.253 & .009 & 2.631 \\
7 & 78.475 & -3.422 & -1.187 & .016 & .779 & 1.253 & .009 & 2.631 \\
\hline
\end{tabular}

a. Method Enter

b. Constant is included in the model

c. Initil-2 Log Likelihood: 138.629

d. Estimation terminated at iteration number 7 because parameter estimtes changed by less than .001

From Table 5, it can conclude that all the independent variables can explain the variation in the probability of credit approval as much as $60.3 \%$, while other factors explain 
the remaining $39.7 \%$ out of the scope of this study. Table 6 aims to find out the percentage of credit approval. The Classification in Table 6 explains that the overall percentage of the predicted variable is $50 \%$ (which is good), and from the comparison of those two values indicates that there is no homoscedasticity problem.

Table 5. Model Summary Test

\begin{tabular}{cccc}
\hline Step & -2 Log Likelihood & Cox \& Snell R-Square & Nagelkerke R-Square \\
\hline 1 & 78.475 & .452 & .603 \\
\hline
\end{tabular}

Note: Estimation terminated at iteration number 7 because parameter estimates changed by less than .001

This test is conducted to find out whether all the independent variables simultaneously affect the dependent variable, and the result can shows in Table 7. Simultaneously, all independent variables have significant effects on credit approval for MSME. The Chi-square value is 60.154 with the degree of freedom 6 , and level of significance 0.000 (which is less than 0.05 ).

Table 6. Classification Table

\begin{tabular}{|c|c|c|c|c|c|}
\hline & \multirow{3}{*}{\multicolumn{2}{|c|}{ Observed }} & \multicolumn{3}{|c|}{ Predicted } \\
\hline & & & \multicolumn{2}{|c|}{ Status } & \multirow{2}{*}{$\begin{array}{c}\text { Percentage } \\
\text { Correct }\end{array}$} \\
\hline & & & Not Approved & Approved & \\
\hline \multirow[t]{3}{*}{$\begin{array}{c}\text { Step } \\
0\end{array}$} & Status & Not Approved & 0 & 50 & .0 \\
\hline & & Approved & 0 & 50 & 100.0 \\
\hline & rcentage & & & & 50.0 \\
\hline
\end{tabular}

a. Constant is included in the model

b. The cut value is .500

From Table 8, it can show that the significance values of Owner's Capital and Good Relationship with the Bank are consecutively 0.012 and 0.000 (less than 0,05), which means that both variables have significant effects on the Probability of Credit Approval at 5\% level. Other variables, which are Company Establishment, Collateral Value, Credit Amount, and Owner's Age, have significance values higher than 0.05, which are 0.780, 0.099, 0.135, and 0.755 . This result means that those four independent variables do not significantly affect the probability of Credit Approval to MSME at 5\% level.

Table 7. Omnibus Test of Model Coeficient

\begin{tabular}{cccc}
\hline & Chi-Square & df & Sig. \\
\hline Step 1 Step & 60.154 & 6 & .000 \\
Block & 60.154 & 6 & .000 \\
Model & 60.154 & 6 & .000 \\
\hline
\end{tabular}


The equation of logistic regressions in this study can be rewriten as follow: $\operatorname{Ln} \frac{\mathrm{p}}{1-\mathrm{p}}=-3.422-1.187 \mathrm{OC}+0.016 \mathrm{CE}+0.779 \mathrm{CV}+1.253 \mathrm{CA}+0.009 \mathrm{OA}+2.631 \mathrm{GR}$

All independent variables (except the Owner's Capital) have positive effects on the Probability of Credit Approval to MSME, but only the Owner's Capital and Good Relationship with the Bank are significant. From the partial test in Table 8, it known that there are significant effects of owner's capital and good relationship with the bank on the probability of credit approval to MSME. In this study, the amount of capital owned by MSME affects the probability of MSME to acquire bank credit. The more the capital owned, the lower the probability of credit approval. Therefore, the relationship between the amount of capital and the probability of credit approval is negative.

Table 8. Variables in the Equation

\begin{tabular}{ccccccc}
\hline & B & S.E. & Wald & df & Sig. & Exp (B) \\
\hline OC & -1.187 & .470 & 6.368 & 1 & .012 & .305 \\
CE & .016 & .057 & .078 & 1 & .780 & 1.016 \\
CV & .779 & .472 & 2.723 & 1 & .099 & 2.178 \\
CA & 1.253 & .839 & 2.230 & 1 & .135 & 3.501 \\
OA & .009 & .028 & .098 & 1 & .755 & 1.009 \\
GR & 2.631 & .716 & 13.519 & 1 & .000 & 13.891 \\
Constant & -3.422 & 1.223 & 7.821 & 1 & .005 & .033 \\
\hline
\end{tabular}

a. Variable(s) entered on step 1: OC, CE, CV, CA, OA, GR

This result is different from those conducted by Ajagbe (2012), Jumhur (2009), and Pato (2013) that concluded that the amount of capital (as part of the financial report) has a positive effect on the probability of credit approval, either formally or informally. This phenomenon is considered new in the financial world nowadays, and it is possible to happen due to the consideration that banks at present days are willing to grant credit approval only to debtors who have less capital. Banks nowadays consider that debtors, who have sufficient capital, may not have the sincerity to apply for bank credit. The partnership is business cooperation among strategic parties, conducted voluntarily, based on the principle of mutual need, mutual support, and mutual advantage, along with coaching and development conducted by larger business parties. The good relationship between debtor and the bank obliges the transparency of the use and direction of the fund. Trust that results from good relationship reduce agency cost and transaction costs in banking relationship (Moro \& Fink, 2013; Fredriksson \& Moro, 2014; Hirsch et al., 2018). This functional relationship also brings every problem to be discussed transparently in order to acquire the best solution for both parties. Thus in this study, 
there is a positive effect of a good relationship with the bank on the probability of credit approval to MSME.

The value of collateral owned by candidate debitors can affect the realization of credit provided by the banks. When a debtor is stated bankrupt and cannot repay the debt, the debtor's collateral asset will execute, and the value will be used to repay the debt. The use of collateral is to provide the right for the bank to get repayment from the sale of collateral whenever a debtor breaches the contract. Collateral value, however, becomes the first and the primary requirement inquired by the bank when applying for the credit.

Afandi (2010), Fitria \& Sari (2012), and Hanis \& Nursyamsi (2013) also concluded that the $5 \mathrm{C}$ principle (including collateral) becomes a critical analysis before credit approval. Furthermore, such a principle also implemented in the matter of credit application requirement, maximum credit limit, and the settlement of the non-performing loan. Lubis \& Rachmina (2011), Pato (2013), Boschi et al., (2017), and Cowan et al., (2015) mentioned that collateral value even becomes an important consideration when deciding on credit approval. For banks, collateral value will reduce the default risk from debtors, because banks can sell their assets to cover the bad debts. The increased proportion of credit guarantee can improve their cost efficiency (Liang et al., 2017).

Company age or establishment can show the capability to overcome difficulties and obstacles that can threaten the life of the company, as well as the capability to take opportunities in developing business. Besides, company establishment can show the company's capability to win the competition. Business experience gets along with age. The older a person's age, then the more his/her business experience. Experience and duration of the establishment will provide an essential lesson in anticipating the market situation and current economic progress. The more business experience possessed, the higher the opportunity of the owners to success because they are already considered smart in managing financial matters. Credit amount or credit ceiling is the amount of loan and period applied in order to used as additional working capital for a production unit based on the assessment on production capacity and working capital necessity (Kasmir, 2004). Gibb \& Ritchie (1982) in Freel et al., (2012) explained that the business owner's age is commonly related to capital and assets. The increases of business owner's age enable them to have higher freedom in financial matters. Individually, they tend to have less attention in acquiring assets but have more attention on financial independence and control. Young entrepreneurs are braver to make speculations in applying for bank credit even though they charged with higher interest. Young people tend to like challenges and behave more actively compared with those with older age who tend to behave passively.

On the contrary, data analysis shows that there is no effect of company establishment, credit amount, and owner's age on the probability of credit approval to MSME. Company establishment and credit amount do not affect the probability of credit approval, because credit relies more on the sufficiency of collateral value and the requirement of the capital amount that have been evaluated by the bank. This result is different from the study 
conducted by Lubis \& Rachmina (2011), which conclude that credit amount applied to the bank significantly affects credit distribution. Also in reality, the older the owner also indicates the lower the necessity of applying for bank credit, because the owners may have more financial independence in their ages. Overall, this study is similar to those conducted previously by Afandi (2010), Messah \& Wangai (2011), Ajagbe (2012), and Pato (2013), in which simultaneously there are significant effects of all independent variables (especially 5C) on the dependent variable (credit approval).

Micro, small, and medium enterprises have some weaknesses. The weaknesses of MSME can be categorized as follows. Based on the aspect of the character, MSME does not have good business administration system (especially in budgeting), human resource quality, raw material availability, and production technology, that results in low productivity. Based on the aspect of capital possession, MSME commonly has limited capital ownership and saving due to small earning generation. Based on the aspect of collateral possessed, MSME has a low capability in providing collateral, either due to the limitation of asset possession or the lack of legality of assets owned. Based on the aspect of repayment capacity, MSME commonly is family-owned companies that have no differentiation between family and business financial administration. This fact may cause difficulty for banks to find out how strong the capability of MSME to repay loan installments. Based on the condition of economics, the uncertainty due to extreme changes in global economics frequently occurs during the last decade. In such conditions, banks tend to increase their prudence in distributing loan causing lower possibility for them to finance business activities that contain high risk, or those that can be easily affected by global economic changes (Subandi, 2007).

Therefore, the government must enhance its role in increasing credit access for smaller firms. Besides that, the government must also provide incentives for informal firms to integrate into the formal economy (Behr et al., 2017; Distinguin et al., 2016). The more support from government for access to credit for MSMEs, it will make MSMEs grow stronger.

\section{Conclusion}

As a result of this study, only the owner's capital and good relationship with the bank have significant effects on the probability of credit approval to MSME, while all the other independent variables do not. Therefore, business owners should pay more attention to the aspect of capital and relationship when applying for bank credit. Business owners should prepare a certain amount of capital possessed when arranging credit proposals, as well as maintaining a good relations with their bank officers. However, the other insignificant predictors should also be taken into account when applying for bank credit. In other words, all the predictors still have to be managed or provided proportionally.

In contrast, the collateral value still becomes the most important criterion for any bank in granting credit application at present. Without the existence of collateral assets, any bank will not approve any credit application. Besides, no study in the past 
proved that collateral does not significantly affect credit approval. Thus the result of this study regarding the collateral matter remains debatable thus can be the subject of further research.

We suggest that in the future, the government-owned bank should also become the object of this study because government-owned and private-owned banks might have different criteria in granting credit approval. Next, debtors should intensively coach in order to enhance their capability to repay the loan; this will increase the probability of another credit approval in the future. Moreover, last, Bank should check on debtors' background more thoroughly. This procedure is necessary in order to seek the correct information on debtors as well as their business activities. If all data provided by debtors is already correct, the bank's trust on debtors will undoubtedly increase, thus will simultaneously increase the excellent relationship between the bank and debtors in the future.

\section{References}

Afandi, P. (2010). Analisis Implementasi 5C Bank BPR dalam Menentukan Kelayakan Pemberian Kredit pada Nasabah: Studi Kasus Pada BPR Bank Salatiga dan PT. BPR Kridaharta Salatiga (Analysis of 5C Implementation on Rural Banks in Determining the Feasibility of Providing Loans to Customers: Study in BPR Salatiga and B PT. BPR Kridaharta Salatiga). Jurnal Ekonomi Dan Akuntansi, 3(5), 55-69.

Ajagbe, F. A. (2012). Application of Profit Analysis to Factors Affecting Small Scale Enterprises Decision to Take Credit: A Case Study of Oyo State, Nigeria. Asian Economic and Financial Review, 2(8), 1064-1071.

Behr, P., Foss, D., \& Norden, L. (2017). Cyclicality of SME Lending and Government Involvement in Banks. Journal of Banking and Finance, 77, 64-77. https:/doi. org/10.1016/j.jbankfin.2017.01.010

Boschi, M., Girardi, A., \& Ventura, M. (2017). Partial Credit Guarantees and SMEs Financing. Journal of Financial Stability, 15, 182-194. https://doi.org/10.1016/j. jfs.2014.09.007

Cowan, K., Drexler, A., \& Yañex, A. (2015). The Effect of Credit Guarantees on Credit Availability and Delinquency Rates. Journal of Banking and Finance, 59, 98-110. https://doi.org/10.1016/j.jbankfin.2015.04.024

De La Torre, A., Periá, M. S. M., \& Schumkler, S. L. (2010). Bank Involvement with SMEs: Beyong Relationship Lending. Journal of Banking and Finance, 34(9), 2280-2293. https://doi.org/10.1016/j.jbankfin.2010.02.014

Degreyse, H., Matthews, K., \& Zhao, T. (2018). SMEs and Access to Bank Credit: Evidence on the Regional Propagation of the Financial Crisis in the UK. Journal of Financial Stability, 38, 53-70. https://doi.org/10.1016/j.jfs.2018.08.006

Distinguin, I., Rugemintwati, C., \& Tacneng, R. (2016). Can Informal Firms Hurt Registered SMEs' Access to Credit? World Development, 84, 18-40. https://doi.org/10.1016/j. worlddev.2016.04.006 
Fitria, N., \& Sari, R. L. (2012). Analisis Kebijakan Pemberian Kredit dan Pengaruh NonPerforming Loan terhadap Loan-to-Deposit Ratio pada Bank Rakyat Indonesia (Persero) Tbk. Cabang Rantau, Aceh Tamiang: Periode 2007-2011 (Analysis of the Policy of Giving Credit and the Effect of Non-Performing Loan to Loan Deposit Ration in Bank of BRI Branch Rantau, Aceh Tamiang: Period 2007-2011). Jurnal Ekonomi Dan Keuangan, 1(1), 88-101.

Fredriksson, A., \& Moro, A. (2014). Bank-SMEs Relationship and Banks' Risk-Adjusted Profitability. Journal of Banking and Finance, 41(67-77). https://doi.org/10.1016/j. jbankfin.2013.12.026

Freel, M., Carter, S., Tagg, S., \& Mason, C. (2012). The Latent Demand for Bank Debt: Characterizing "Discouraged Borrowers." Small Business Economics, 38(4), 399-418. https://doi.org/10.1007/s11187-010-9283-6

Gibb, A. A., \& Ritchie, J. R. (1982). Understanding the Process of Starting Small Businesses. European Small Business Journal, 1, 26-45.

Hanis, U., \& Nursyamsi, J. (2013). Pengaruh Prasyarat Kredit terhadap Kelancaran Pembayaran Nasabah: Studi Kasus Nasabah pada PT. Bank Bukopin Kantor Cabang Pembantu Cilegon (Effects of Credit Prerequisites on Smooth Customer Payments: Customer Case Study at PT. Bank Bukopin Sub-Branch Office Cilegon). UG Jurnal, 7(5), 8-11.

Hirsch, B., Nitzl, C., \& Schoen, M. (2018). Interorganizational Trust and Agency Costs in Credit Relationship Between Savings Bank and SMEs. Journal of Banking and Finance, 97, 37-50. https://doi.org/10.1016/j.jbankfin.2018.09.017

Jumhur. (2009). Analisis Permintaan Kredit Modal Kerja Usaha Kecil di Kota Pontianak (Analysis of Demand for Small Business Working Capital Loans in Pontianak City). Jurnal Bisnis Dan Ekonomi, 16(2), 85-96.

Kasmir. (2004). Bank \& Lembaga Keuangan Lainnya (Bank and Other Financial Institutions). Jakarta: RajaGrafindo Persada.

Liang, L. W., Huang, B. Y., Liao, C. F., \& Gao, Y. T. (2017). The Impact of SMEs' Lending and Credit Guarantee on Bank Efficiency in South Korea. Review of Development Finance, 7(2), 134-141. https://doi.org/10.1016/j.rdf.2017.04.003

Lubis, A. M., \& Rachmina, D. (2011). Faktor-Faktor yang Mempengaruhi Realisasi dan Pengembalian Kredit Usaha Rakyat (Factors Affecting the Realization and Return of People's Business Loans). Agribusiness Forum, 1(2), 112-131.

Messah, O. B., \& Wangai, P. N. (2011). Factors That Influence the Demand for Credit for Credit among Small-Scale Investors: A Case Study of Meru Central District, Kenya. Research Journal of Finance and Accounting, 2(2), 74-101.

Moro, A., \& Fink, M. (2013). Loan Managers' Trust and Credit Access for SMEs. Journal of Banking and Finance. Journal of Banking and Finance, 37(3), 927-936. https://doi. org/10.1016/j.jbankfin.2012.10.023

Pato, S. (2013). Analisis Pemberian Kredit Mikro pada Bank Syariah Mandiri Cabang Manado (Analysis of Provision of Micro Loans to Bank Syariah Mandiri, Manado Branch). Jurnal EMBA, 1(4), 875-885. 
Rudiantoro, R., \& Siregar, S. V. (2012). Kualitas Laporan Keuangan UMKM serta Prospek Implementasi SAK ETAP (Quality of MSME Financial Reports and Prospects for Implementation of SAK ETAP). Jurnal Akuntansi Dan Keuangan Indonesia, 9(1), 1-21.

Subandi, S. (2007). Potensi Pengembangan Permodalan UMKM dari Pinjaman Perbankan (Potential Development of MSME Capital from Banking Loans). Majalah Infokop, 15(2), 1-12.

Susilo, Y. S. (2010). Peran Perbankan dalam Pembiayaan UMKM di Propinsi DIY (The Role of Banking in Financing MSMEs in DIY Province). Jurnal Keuangan Dan Perbankan, 14(3), 467-478. 